\title{
WAIVER AND ESTOPPEL IN INSURANCE LAW
}

\author{
WIILIAM R. VANCE
}

The twenty-two years that have passed since the Supreme Court of the United States handed down its opinion in the case of Northerm Assurance Co. v. Grand View Buitding Assoc. ${ }^{1}$ have done little to clear away the wordy fog which that famous case did so much to raise about the doctrines of waiver and estoppel in insurance law. Stripped of trappings, the main point determined by that case was that an insurance company might deliver to an honest applicant for insurance a piece of paper having the appearance of an insurance policy, take from him the price of a sound contract, and leave him under the belief that he had actually secured the protection for which he had applied and paid, and still be allowed in an action at law to show that, by reason of the breach ${ }^{2}$ of a condition precedent, known all the time to its officiating agent, it had assumed no obligation to pay. Incidentally, in assessing the fireside equities, one recalls that in practice the insurer would not be required to return the premium unless the occurrence of a loss should afford unhappy occasion to the duped applicant to learn that he had received no consideration for his premium payment. The essential inequity of this result was recognized when in a later appeal

${ }^{1}$ (I902) I83 U. S. 308, 22 Sup. Ct. I33. "... . The case of Union Mut. Life Ins. Co. v. Wilkinson, and the other cases in the Supreme Court of the United States along the same line, were 'distinguished' in name, but in fact were overruled, and the Wilkinson Case was almost in terms overruled." Hill, C. J., in People's Fire Ins. Ass'n v. Goyne (I906) 79 Ark. 315, 96 S. W. 365. This masked zeversal of opinion had been foreshadowed by vigorous dictum. in New York Life Ins. Co. v. Fletcher (I886) II7 U. S. 5I9, 6 Sup. Ct. 837, but in that case the diseased insured was, in effect, joining the unfaithful agent of the insurer in an attempt to defraud the insurer, and therefore in no position to claim an equitable estoppel. In Continental Life Ins. Co. v. Chamberlain (1889) 132 U. S. 304, 10 Sup. Ct 87 , the opinion by Mr. Justice Harlan shows a tendency to return to the doctrine of the Wilkinson case, but in Aetna Life Ins. Co. v. Moore (1913) 23I U. S. 543, 34 Sup. Ct. 186, the Supreme Court expressly discredited, if it did not overrule, not only the Wilkinson case, but also the Chamberlain case. In the most recent decision of the Supreme Court in which the Northern Assurance Co. case was cited with approval, Mut. Life Ins. Co. v. Hilton-Green (I9I6) $24 \mathrm{I}$ U. S. $613,624,36$ Sup. Ct. 676,680 , the insured participated in the fraud of the insurer's agents, and therefore was clearly not entitled to claim an equitable estoppel.

"The use of the expression "breach of condition" is objectionable inasmuch as it suggests a breach of duty, whereas a condition seldom imposes a duty. It usually confers only a privilege which may be exercised or not at the option of the person to whom it is given. For such a condition the term "non-fulfillment" would seem more appropriate. But there are other conditions which involve states of fact or events beyond the control of the parties to the contract. For these the words "non-existence" and "non-occurrence" are more fitting. In the interest of simplicity and brevity of statement it is thought better to use the customary phrase "breach of condition" as connoting conventionally all of these several concepts. 
in a case involving the same transaction and the same parties, the Supreme Court held that the insured was entitled to his money if only he went about getting it in the right way, viz... by a bill in equity to reform the contract. ${ }^{3}$

An attempt to state more specifically the issues determined by this famous case proves difficult, as the confused opinion resists analysis. The opinion states" that "The question before us is therefore reduced to one of waiver." Nowhere does the opinion indicate that the writer, Mr. Justice Shiras, appreciated a possible distinction between waiver of a known defense and estoppel to set up an inequitable defense, a distinction previously made with reasonable clearness in Union Mutual Ins. Co. v. Wilkinson ${ }^{5}$ and subsequent cases. Even when he uses language competent to describe an estoppel, he understands only a waiver. After stating the doctrine of estoppel as established by the New York cases, he comments:" "This mode of reasoning overlooks both the general principle that a written contract cannot be varied or defeated by parol evidence, and the express provision that no waiver shall be made by the agent except in writing indorsed on the policy."

Again, after stating the plaintiff's claim of estoppel thus," "The plaintiff's case stands solely on the proposition that because it is alleged, and the jury have found, that the agent had notice or knowledge of the existence of insurance existing in another company at the time the policy in suit was executed and accepted, and received the premium called for in the contract, thereby the insurance company is estopped from availing itself of the protection of the conditions contained in the policy," he proceeds to interpret it as a mere waiver ; "In other words, the contention is that an agent with no authority to dispense with or alter the conditions of the policy could confer such power upon himself by disregarding the limitations expressed in the contract, those limitations being according to all the authorities presumably known to the insured." The opinion laboriously establishes that the parol evidence rule, prohibiting the alteration or contradiction of written contracts by proof of prior or contemporaneous parol agreements, applies to insurance contracts, and then appears to rest its decision in favor of the defendant on the ground that since the insured was bound to know the limitations imposed by the policy upon the agent's authority, the insurer was not bound by the agent's implied waiver at the time of delivering the policy. It is obvious, however, that if the facts are to be interpreted as a waiver, or an implied agreement in modification of the policy made at the inception of the contract, the

${ }^{3}$ No. Assur. Co. v. Grand View Bldg. Assoc. (1906) 203 U. S. I06, 27 Sup. Ct. 27 , affirming s. c. (Ig06) $73 \mathrm{Neb}$. I49, I02 N. W. 246.

${ }_{183}$ U. S. at p. 317,22 Sup. Ct. I36.

(I87r, U. S.) I3 Wall. 222.

183 U. S. at p. 328,22 Sup. Ct. I40.

'I83 U. S. at p. 362, 22 Sup. Ct. I53.

${ }^{8} 183$ U. S. 363,22 Sup. Ct. 153. 
question of the authority of the agent making the agreement is immaterial. A parol agreement made at the time of delivering the policy would be wholly ineffective to modify its terms, whether made by the president of the company or the office boy. And such was the decision in Lumber Underwriters $v$. Rife. ${ }^{9}$ The point really determined by the long and tortuous opinion of the court would seem then to be that the alleged estoppel was but a claim of waiver at the delivery of the policy; that such waiver was but an implied parol agreement in contravention of the terms of the policy, and therefore could not be shown. It would seem, then, to follow that the long discussion of the effect of the limitations upon the agent's authority to waive, however material it would have been if the alleged waiver had occurred subsequently to the delivery of the policy, was, under the facts of this case, quite unnecessary.

Prior to the decision of the Northern Assurance Co. case, the courts of most of the states ${ }^{10}$ had either expressly accepted or referred with approval to the doctrine laid down in I87I by Mr. Justice Miller in Union Mutual Life Ins. Co. v. Wilkinson, ${ }^{11}$ which, in turn, followed some earlier New York cases, ${ }^{12}$ that even in an action at law on the policy testimony might be received to show that a breach of condition precedent to the inception of the policy upon which the insurer relied to defeat the claim of an honest insured, was known to the insurer or his agent at the time the policy was delivered, and that the insurer was thereby estopped from claiming the benefit of such a dishonest defense. It is quite true that in the Wilkinson case and those following it the reasons given for admitting such evidence were frequently confused, and the theory of equitable estoppel to deny the asserted validity of the contract was sadly confused with that of waiver of a privilege under the contract, yet the course of actual decision was fairly consistent, and through the confused language of the opinions there can clearly be discerned, the persistent idea that the insurer should not be allowed by his actions to assert the validity of the policy when taking the insured's money, and deny it when called upon to pay his loss. ${ }^{13}$

\footnotetext{
'(I915) 237 U. S. 605, 35 Sup. Ct. 7I7.

${ }^{10}$ See the vast array of cases cited in 3 Cooley, Briefs on Insurance (Ig05) 2621 et seq., and in 32 C. J. 1343, note 66 . Many others might be added.

${ }^{11}$ Supra note 5 .

${ }^{23}$ Plumb v. Cattarangus Co. Mntt. Ins. Co. (I858) I8 N. Y. 392; Rowley v. Ins. Co. (I867) 36 N. Y. 550.

${ }^{13}$ See Cue v. Conn. Fire Ins. Co. (1913) 89 Kans. 90, 130 Pac. 664, in which the court quotes with approval the opinion of Ladd, J., in Gurnett $v$. Ins. Co. (Ig04) I24 Iowa, 547, 549, 100 N. W. 542, 543, as follows: "The law is charitable enough to assume, in the absence of any showing to the contrary, that an insurance company intends to execute a valid contract in return for the premium received; and when the policy contains a condition which renders it void at its inception, and this result is known to the insurer, it will be presumed to have intended to waive the condition, and to execute a binding contract, rather than to have deceived the insured into thinking his property is insured when it is not, and to have taken his
} 
In several of the states this course of decision was seriously disturbed by the Northern Assurance Co. case. The great prestige of the Supreme Court, coupled with the apparently exhaustive consideration of the question in that case, caused some of the state courts to reconsider the matter and to follow the federal supreme court in its changed ruling. But the revulsion came quickly. ${ }^{14}$. The wavering courts returned to their earlier precedents and it is believed that at the present time such parol estoppels may be shown in the courts of every state ${ }^{15}$. of the Union except Massachusetts ${ }^{16}$ and New Jersey. ${ }^{17}$ These two states have consistently refused to admit offered proof of such estoppels on the ground that to do so would be to violate the

money without consideration." See also the picturesque opinion of Doe, C. J., in DeLancey v. Rockingham Fire Ins. Co. (1873) 52 N. H. $58 \mathrm{r}$.

${ }^{14}$ Compare Manpin v. Scottish Union Ins. Co. (I903) 53 W. Va, 557, 45 S. E. 1003, with Medley v. German Alliance Ins. Co. (1904) 55 W. Va. 342, 47 S. E. ror. Both cases contain elaborate discussions of the Northerm Assurance Co. case, a majority of the court approving it in the former case, and refusing to follow it in the latter. The Maupin case, however, did not involve an estoppel such as was denied in the Northern Assurance Co. case, but an attempted parol waiver at the time of the issuance of the policy, which was very properly held inadmissible. In State Mut. Ins. Co. v. Craig (I9I0) 27 Okla. 90, III Pac. 325, the court repudiated the Federal rule applied in Sullivan v. Merc. Mut. Ins. Co. (Ig08) 20 Okla. 460, 94 Pac. 676, the trial of the latter case having taken place before Oklahoma became a state. See also People's Fire Ins. Co. v. Goyne, supra note I; Leisen v. St. Paul F. \& M. Itus. Co. (I910) 20 N. D. 316, 127 N. W. 837, overruling Lamb v. Merchants', Nat. Ins. Co. (I909) I8 N. D. 253, II9 N. W. I048. See also Pearlstine v. Phoenix Ins. Co. (1906) 74 S. C. 246, 54 S. E. 372 ; Virginia F. \& M. Irs. Co. v. Richmond Mica Co. (Irg04) ro2 Va. 429, 46 S. E. 463 ; Welch v. Fire Assoc. (1904) I20 Wis. 456, 98 N. W. 227.

${ }^{25}$ See notes 10 and 14 supra. Quite a number of decisions cited as following the Northem.Assurance Co. case merely accept the rule stated in that case that the insurer cannot be estopped by the unauthorized acts of its agents. See Iverson $v$. Met. Life Ins. Co. (1907) I5I Calif. 746, 9I Pac. 609; Layton v. N. Y. Life Ins. Co. (I92I) 55 Calif. App. 202, 202 Pac. 958; N. Y. Life Ins. Co. v. Patten (I92r) I5I Ga. 185, I06 S. E. I83; Forwood v. Prudential Ins. Co. (I9I2) II7. Md. 254, 83 At1. I69; Tuttle v. Pac. Mut. Ins. Co. (1920) 58 Mont. I2I, 190 Pac. 993. The courts of Rhode Island still reluctantly maintain the obsolescent doctrine that the soliciting agent is to be regarded, in so far as he aids in preparing the application, as the agent of the insured, and not of the insurer. Salvate $v$. Firemen's Ins. Co. (I920) 42 R. I. 433, 108 Atl. 579; Reed v. Equitable F. \& $M$. Ins. Co. (I892) I7 R. I. 785, 24 Atl. 833. But this rule does not apply to the insurer's medical examiner while acting in the scope of his employment. Leonard v. State Mut. Life Assur. Co. (1902) 24 R. I. 7, 5 I Atl 1049. In Georgia it is curiously held that the insurer may be estopped by the unauthorized acts of his agent in making life, but not fire insurance contracts. $N$. Y. Life Ins. Co. $v$. Patten, supra. But in none of these cases is it denied that the insurer may be estopped by the acts of a competent agent to claim a forfeiture from a known breach of condition.

${ }^{20}$ Harris v. No. Amer. Ins. Co. (1905) I90 Mass. 36r, 77 N. E. 493 ; Batchelder v. Quecu Ins. Co. (1883) I35 Mass. 449 .

${ }^{17}$ Franklin Fire Ins. Co. v. Martin ('1878) 40 N. J. L. 568; Dewees v. Manhattan Ints. Co. (I872) 35 N. J. L. 366. 
so-called parol testimony rule. The English courts also still maintain with less of certainty the same position. ${ }^{18}$

The inferior Federal courts sitting in states where the doctrine of parol estoppels is accepted by the state courts as a matter of course, and yet compelled to follow the Federal rule because a question of general commercial law is involved, ${ }^{19}$ have naturally shown themselves restive under the rule imposed by the Supreme Court in the Northern Assurance Co. case. As might have been expected, the process of distinguishing away that case was soon under way, but this was rudely interrupted by the Supreme Court. The Circuit Court of Appeals for the Sixth Circuit had held ${ }^{20}$ that an insurance company which, with exact knowledge of the character of the risk gained through a report by its own inspector, had issued a fire policy and taken the insured's money as a premium therefor, was estopped to claim the benefit of the condition avoiding the policy in case other buildings were located within one hundred feet of the structure to be covered, a condition known by the insurer to be broken as soon as made. But by a writ of certiorari the Supreme Court brought the Circuit Court of Appeals roundly about, saying:"1 "Therefore when by its written stipulation the document

\footnotetext{
${ }^{28}$ It appears to be settled law in England that the soliciting agent who aids in the preparation of the application is deemed to be the agent of the insured and not of the insurer. It necessarily follows, therefore, that the insurer is held not to be estopped to take advantage of false answers inserted by the soliciting agent in the application form even when true answers have in fact been given by the insured to the agent. See Biggar v. Rock Life Assur. Co. [1902] I K. B. 5I6; Dazesons v. Bonnin [1922, H. L.] 2 A. C. 4I3. Note, however, at p. 439 , the dissenting opinion of Lord Wrenbury, who thinks that an estoppel should be found in such a case. The present state of the English authorities does not make it at all clear that the English courts would refuse to enforce an estoppel in pais if the acts upon which the alleged estoppel was based were done by one having authority to bind the insurer. Thus in Morrison v. Universal Marine Ins. Co. (I872) L. R. 8 Exch. 40, at p. 53, Martin, B., makes the following, statement: "If the underwriter, after having acquired a knowledge of the facts of concealment, gives out

- a policy without notice and as if it were binding on him, he does that which would induce the assured to think that he had a valid policy and to seek no further for insurance. He cannot be allowed to wait until a loss has occurred and then elect to rescind when his own act has put the assured in a condition in which he can no longer insure himself anywhere." The judgment of the Court of Exchequer was reversed on appeal to the Exchequer Chamber (1873) L. R. 8 Exch. 197, not on the ground that no such estoppel could be shown, but rather because the evidence did not show all the elements of an estoppel. That is to say, the proof failed to show that the insured had in fact.relied to his prejudice upon the act of the insturer. See also Holdsworth v. Lanc. \& York. Ins. Co. (1907, K. B.) 23 T. L. R. 521 ; Bower, Estoppel (1923) 373.

${ }^{20}$ Aetna Life Ins. Co. v. Moore, sutpra note I; MacKelvie v. Mut. Ben. Life Ins, Co. (I923, C. C. A. 2d) 287 Fed. 660.

${ }^{20}$ Rife v. Lumber Underweriters (1913, C. C. A. 6th) 204 Fed. 32. The court's opinion makes no distinction between waiver and estoppel, using the terms interchangeably.

${ }^{21}$ Lumber Underzeriters v. Rife, supra note 9, at p. 609, 35 Sup. Ct. 717. The Chief Justice and Justices McKenna and Day dissented, expressly approving the
} 
gave notice that a certain term was insisted upon, it would be contrary to the fundamental theory of the legal relations established to allow parol proof that at the very moment when the policy was delivered that term was waived. It is the established doctrine of this court that such proof cannot be received." But even in the face of such a rebuke, the Circuit Courts of Appeal probably feel that there must be some limit to the application of the hard rule insisted upon by the Supreme Court. The Circuit Court of Appeals for the Second Circuit evidently considered that the limit had been passed when an insurance company, after refusing an application for insurance on a certain barge because its inspector reported it to be unseaworthy, subsequently granted the insurance at a much higher rate because of the unseaworthiness, but thriftily included a warranty of seaworthiness in the policy issued. The judgment of the court that the insurer was estopped to set up a breach of this warranty appears to have remained undisturbed. ${ }^{22}$

It is sufficiently unfortunate that as to these cases of true estoppels now under discussion there should be such a lack of harmony of decision with regard to so important a question of commercial law between the state and federal courts. But when we come to combine questions of waiver with those of estoppel, both being often complicated by difficult accompanying questions as to the powers of agents, we find a confusion of decision as well as of statement that is truly distressing. ${ }^{23}$ In this connection waivers and estoppels are sometimes carefully distinguished as independent concepts ${ }^{24}$ and sometimes regarded

decision of the Circuit Court of Appeals. The failure of the court to make any distinction between a waiver, which certainly could not be shown under the circumstances stated, and the estoppel found by the lower court, is remarkable.

$=$ "If the [insurer] knowingly took the risk at a higher premium it should be held to its bargain, and not be permitted to resort to the terms of the policy to overcome the claim." Amer. Marine Ins. Co. v. Ford Corp. (Ig20, C. C. A. 2d) 269 Fed. 768, 770. See (192I) 30 YALE LAW JourNAI, 763; also Hanover Fire Isw. Co. v. Dallavo (I92I, C. C. A. 6th) 274 Fed. 258, where, however, a true waiver was involved.

${ }^{2}$ As careful a judge as Lord Eldon uses the following language: "As to waiver, it is difficult to say precisely what is meant by the term with reference to the legal effect. A waiver is nothing unless it amounts to a release. It is by a release or something equivalent only that an equitable demand can be given away. A mere waiver signifies nothing more than an expression of intention not to insist upon the right, which in equity will not, without consideration, bar the right any more than, at law, accord without satisfaction would be a plea." Stackhouse v. Barmston (I805, Ch.) Io Ves. Jr. $453,466$.

* See Johinson v. Aetna Ins. Co. (1905) I23 Ga. 404, 5I S. E. 339; Bemis v. Casualty Co. (1914) 125 Minn. 54, I45 N. W. 622; Redstrake v. Cumberland Mut. Fire Ins. Co. (1882) 44 N. J. L. 294; Welch v. Fire Assoc. supra note I4.

"Counsel's criticism of certain of the New York cases shows that he apparently fails to distinguish between a waiver and an estoppel." Fisk, J., in Leisen $v$. St. Paul F. \& M. Ins. Co. supra note I4, at p. 335, I27 N. W. 845 . "While that doctrine [waiver] and the doctrine of equitable estoppel are often confused in 
as complementary, ${ }^{25}$ but, unfortunately, most frequently the terms are treated as essentially synonymous. ${ }^{26}$ As an illustration of this prevailing confusion of thought and statement we may quote the following passage from a recent admirable treatise on insurance : ${ }^{27}$ "Any unequ1vocal and positive act by the insurers recognizing the policy as valid and inconsistent with the notion that the company proposes to avail itself of a breach.... constitutes a waiver of all known grounds of forfeiture, and the company is said to be estopped from setting them up in defense, provided the insured can show that by such act he has been misled to his injury." Not less confusing is the oft-quoted statement, made in Globe Mutual Life Ins. Co. v. Wolff. ${ }^{28}$ What the court decided was that an alleged waiver fraudulently obtained from an unauthorized agent was not binding on the insurer, but what Mr. Justice Field, writing for the court, said was this: "The doctrine of waiver, as asserted against insurance companies to avoid the strict enforcement of conditions contained in their policies, is only another name for the doctrine of estoppel. It can only be invoked where the conduct of the companies has been such as to induce action in reliance upon it, and where it would operate as a fraud upon the assured if they were afterwards allowed to disavow their conduct and enforce the conditions."

It is believed that much of this confusion in language and discord in decision can be removed by a careful analysis of the typical fact situations in insurance law to which the terms waiver and estoppel are applied, and discovering what is really meant when either or both terms are used. It will be found that however uncertain the meaning of the word waiver, and however many varying concepts it may

insurance litigation, there is a clear distinction between the two." Cullen, C. J., in Draper v. Oswego Co. F. R. Assoc. (I907) I90 N. Y. I2, I6, 82 N. E. 755, 756. See also the extended discussion in Craine v. Colonial Mut. Fire Ins. Co. (I920, Austr.) 28 C. I. R. 305.

${ }^{25}$ See Bennett v. Union Cent. Life Ins. Co. (I903) 203 I11. 439, 67 N. E. 97x; Robinson v. Penn. Fire Ins. Co. (I897) 9o Me. 385,38 Atl. $320 ; N$. Y. Life Iits. Co. v. Eggleston (I877) 96 U. S. 572 .

${ }^{26}$ Northern Assur. Co. v. Grand View Bldg. Assoc. supra note I; .Iverson v. Met. Life Ins. Co. supra note 15; Wisdom v. Farm Prop. Mut. Ins. Assoc. (1925, Iowa) 202 N. W. 5 ; Oatman v. Bankers' Mut. F. R. Assoc. (1913) 66 Or. 388, I34 Pac. I033.

"The doctrine of waiver, as applied to such a case as this, is that of estoppel in pais. There is no substantial distinction between the two, and the terms are used interchangeably, a waiver being only another name for an estoppel." Cartwright, J., in Phenix Ins. Co. v. Grove (1905) 2I5 Ill. 299, 302, 74 N. E. I4I, I42. In the valuable note in I6 L. R.A. (N. s.) II65, is found at p. I2I8, the following statement: "In many of the cases the knowledge of the agent, instead of being held to estop the company, is held to amount to a waiver. The distinction, however, as applied to insurance cases, does not seem to be of importance, since the terms appear to be used as synonymous."

${ }^{27}$ Richards, Insurance (3d ed. I9I6) I7I.

${ }^{23}$ (1877) 95 U. S. $326,333$. 
include, ${ }^{29}$ it is nevertheless a useful term, connoting a group of legal relationships that have many incidents in common, and which, in the vast majority of cases, are easily distiguishable from estoppels, although here, as elsewhere in the law, we find borderland cases which present facts that may be interpreted as raising the one or the other as the emphasis is shifted. ${ }^{30}$

\section{WAIVERS}

First considering the typical fact situations to which courts and text-writers most frequently apply the term waiver, we will assume that in all cases the agent acting for the insurance company is empowered to bind it by word or act. Such in fact is often not the case, but for our present purposes it is desirable to exclude the complicating questions introduced by limitations upon the powers of agents. These will be considered only incidentally.

Case (I). Jones informs the agent of the insurer that he will not apply for life insurance since he is about to enter military service, which he knows is contrary to a condition in the policy proposed. The agent replies that his company is one hundred per cent. patriotic and will not enforce that condition. Jones thereupon makes application and duly receives a policy in which is written a condition that it shall become void if the insured engages in military service without the consent of the company endorsed thereon. Jones thereafter, without such endorsed consent, enlists in the army and is killed in France. In an action on this policy Jones' administrator seeks to avoid the insurer's defense of breach of condition by offering evidence that it was waived before the making of the contract.

Here we clearly have an attempt to show a preliminary parol agreement which was not incorporated in the subsequent written contract, and therefore was "merged" in it. Such a preliminary agreement, whether written or parol, cannot be shown in contradiction of the policy. ${ }^{31}$ The so-called "parol testimony rule" based on common sense, and so essential to the integrity of business engagements, cannot be evaded merely by calling the preliminary agreement a waiver or even

${ }^{2}$ In 2 Williston, Contracts (I920) sec. 679, are listed no fewer than nine legal relationships to which the term waiver is indifferently applied.

${ }^{30}$ For example, in many cases denial of all liability under the policy is held to esiop the insurer from claiming as a defense the failure of the insured to furnish proofs of loss as required by the policy. See Robinson v. Pem. Fire Ins. Co. supra note 25; Butterworth $v$. West. Ins. Co. (I882) I.32 Mass. 489. Such conduct may easily be interpreted as a waiver. See cases cited in note 43 , infra.

${ }^{31}$ Insurance Co. v. Mozery (1877) 96 U. S. 544; Pemman v. St. Paul Ins. Co. (19I0) 216 U. S. $3 \mathrm{II}, 30$ Sup. Ct. 3Ix; Home Fire Ins. Co. v. Wilson (Igr3) 109 Ark. 324, I59 S. W. IIr3; Calmenson v. Insurance Co. (I904) 92 Minn. 390, 100 N. W. I88; Untion Cent. Life Ins. Co. v. Hook (Ig0o) 62 Ohio St. 256, 56 N. E. 906; Met. Life Ins. Co. v. Hall (r905) ro4 Va. 572, 52 S. E. 345. 
an estoppel. The few decisions that have allowed such a "waiver" to be set up as an estoppel are much to be regretted. ${ }^{32}$

Case (2). A life policy having been tendered to Jones according to his application, he reads it and discovers the condition with regard to military service, and refuses to accept it. Thereupon the agent says, "We will waive that clause." Satisfied with this assurance, Jones accepts the policy and enlists.

Here also is a parol agreement inconsistent with the terms of the written contract, made contemporaneously' with its delivery, and also "merged" in it. The same considerations as in the preceding case preclude its being shown in an action at law.

Case (3). Jones, having an existing policy containing the antimilitary condition, informs the agent of his desire to enlist and asks a waiver of the condition. The agent replies: "Certainly. We will not enforce that condition. It is waived." Acting on such promise, Jones enlists.

Here again we have an agreement made upon adequate consideration, being a promise for an act impliedly requested, operating to modify the existing written agreement. There is no reason whatever why a written policy contract shall not be subsequently modified by parol agreement. The courts uniformly admit evidence of such subsequent parol "waivers." The question usually litigated is not the admissibility of the evidence, but the authority of the agent to make the modifying agreement or waiver. ${ }^{34}$

Case (4). Jones, having such a policy, serves in the army without injury and is discharged. He informs the agent of these facts, and tenders the next accruing premium. The agent accepts the premium saying that while the policy had been forfeited the company will waive the forfeiture.

Here we have an agreement on valuable consideration-the payment of the premium,-but it is not made in modification of the policy contract, which still remains unchanged, including the anti-military clause. It accomplishes merely the relinquishment of the insurer's privilege to set up an otherwise perfectly valid defense to any action on the policy. This may very properly be called a waiver. It will be enforced by all

\footnotetext{
"Sovereign Camp v. Richardson (I92I) I5I Ark. 23I, 236 S. W. 778. See also Pfiester v. Mo. State Life Ins. Co. (IgrI) $85 \mathrm{Kan}$. 97, II6 Pac. 245. "However keen the disappointment of the insured may have been, nevertheless he was neither deceived nor misled." (Ig22) 3I YaIE LAW JouRNaI, 778.

${ }^{33}$ Ins. Co. v. Norton (1877) 96 U. S. 234; Hartford Life Ins. Co. v. Unisell (1892) I44 U. S. 439, I2 Sup. Ct. 67I; Amer. Fire Ins. Co. v. King Lumber Co. (I9r9) 250 U. S. 2, 39 Sup. Ct. 43I; Hastings v. B'klyn. Life Ins. Co. (I893) I38 N. Y. 473, 34 N. E. 289; Graham v. Sec. Mut. Life Ins. Co. I905) 72 N. J. L. 298, 62 Atl. 68I; Holdsworth v. Lanc. \& York. Ins. Co. stupra note I8; Wing v. Harvey (1854, Ch.) 5 DeG. M. \& G. 265; 2 Cooley, op. cit. 2658 et seq.; 16 L. R. A. (N. S.) II7I, note.

"See Peterson v. Modern Woodmen (I923) I27 Wash. 412, 220 Pac. 809. Obviously such a waiver by an agent not authorized to make it, should not be binding upon the insurer. Banmgartel v. Prov. Wash. Ins. Co. (I893) I36 N. Y. 547, 32 N. E. 990; Met. Life Ins. Co. v. Hall supra note 3r.
} 
courts, whether the waiver be express, or only implied from acceptance of the premium by the insurer with knowledge of the breach of condition. ${ }^{35}$

Case (5). Jones secures a fire policy which by its terms is "void" in its inception because he has other insurance on the building covered. Subsequently the insurer, being informed of the breach of condition, expressly excuses it and accepts payment of a deferred premium.

Here we have what may be termed a subsequent waiver of a breach of condition precedent to the inception of the contract, which all courts agree may be shown by parol. ${ }^{36}$ If it were true that the contract had no inception until the waiver, we should here have a parol waiver contemporaneous with the making of the contract, which would be subject to the same objections as in Case (2) stated above. But in fact the contract does have its inception with delivery to the insured, though it is voidable at the option of the insurer, not of the insured $;^{37}$ that is, the insurer has the power to avoid the entire contract if he so elects. It is this power which he subsequently waives. Such a waiver cannot be obnoxious to the parol testimony rule.

Case (6). Jones, having a life policy containing the anti-military clause, enlists without the consent of the insurer, but is shortly afterwards discharged with health unimpaired. The agent of the insurer thereupon writes him a letter stating that the company takes pleasure in reinstating his forfeited policy. Jones then dies before paying another premium, or doing any other act in reliance upon the letter of rein-

\footnotetext{
"Phoenix Mut. Life Ins. Co. v. Raddir (I887) I20 U. S. I83, 7 Sup. Ct. 500; Hennessy v. Met. Life Ins. Co. (Ig02) 74 Conn. 699, 52 Atl. 490; Germania Fire Ins. Co. v. Koehler (1893) I68 Ill. 293, 48 N. E. 297; Monahan v. Mut. Life Ins. Co. (1906) 103 Md. I45, 63 Atl. 211; McNicholas v. Prudential Ins. Co. (1907) I96 Mass. 565,82 N. E. 692 . Some courts seem to regard a waiver supported by consideration (payment of an unearned premium) as the making of a new contract. See Lartz v. Vermont Ins. Co. (I89I) $139 \mathrm{~Pa}$. 546, 21 At1. 80. But the insurer does not waive a breach of condition by receiving or enforcing payment of a premium already earned before such breach. Burner v. German-American Ius. Co. (I898) I03 Ky. 370, 45 S. W. I09; Lesseps v. Fidelity Mut. Life Ins. Co. (1908) I20 La. 610, 45 So. 522.

${ }^{2}$ Phoenix Mut. Life Ins. Co. v. Raddin, supra note 35; Hanover Fire Ins. Co. v. Dallavo, supra note 22 (mere retention of unearned premiums); Masonic Life Ins. Co. v. Robinson (I9r2) $149 \mathrm{Ky} .80$, I47 S. W. 882; Wood v. Amer. Fire Ins. Co. (1896) I49 N. Y. 382, 44 N. E. 80; Armstrong v. Turquand (1858, C. P.) 9 Ir. C. L. 32; Morrison v. Universal Marine Ins. Co. supra note I8. Cf. Marine Ins. Act (I906) 6 Edw. VII, c. 4I, sec. 34 (3). "A breach of warranty may be waived by the insurer."

${ }^{37}$ See cases cited in notes 74-78 infra. It is sometimes declared, however, that upon breach of condition the policy in suit became ipso facto void, and could be revived only by a new contract, supported by a "consideration or an estoppel." See New York Cent. Ins. Co. v. Watson (187I) 23 Mich. 486; Carpenter v. Cont. Ins. Co. (I886) 6r Mich. 635, 28 N. W. 749; New v. German Ins. Co. (I892) 5 Ind. App. 82, 31 N. E. 475 (alienation by insured); Behling v. N. W. Nat. Life Ins. Co. (Ig03) II7 Wis. $24,93 \mathrm{~N}$. W.' 800 (failure to pay premium note). No case is known to the writer in which such a declaration was really necessary to the decision. See comment on such statements in Ewart, Waiver Distributed (I9I7) 50,5 I.
} 
written contract, and not to recitals, has no application whatever. The statement. The insurer has extinguished his privilege to set up the breach of condition. ${ }^{38}$

Case (7). Jones, having an existing life policy, enlists contrary to the condition therein, and is killed in France. The insurer writes to the widow-beneficiary: "Your husband's policy was forfeited by his entering military service, but since he died for his country, we have decided to pay the full amount of the policy." Later the insurer refuses to pay. It seems that such a waiver, though without the support of any consideration, is sufficient to extinguish the insurer's privilege to set up the breach of condition. ${ }^{39}$

Case (8). Jones' accident policy contains a provision excepting from the risks covered by the contract death or injury suffered on account of riding in an aeroplane. Jones is killed while engaged in aviation, but the sympathetic insurer, with full knowledge of the facts, agrees to waive the exception. Such a waiver is not binding unless supported by a consideration. ${ }^{40}$

Case (9). The insurance company's agent tenders to Jones a life policy containing a stipulation that it shall not take effect until actually delivered to the insured while he is in good health, and the first premium is actually paid in cash. Jones explains that he has not the ready money, and offers to give his note at three months for the premium. The agent accepts the note and delivers the policy. Jones dies within the three months. Is the insurer under a duty to pay?

At first it seems that we have a situation similar to that in Case No. 2, involving an agreement contemporaneous with the making of the written contract and contradicting one of its terms, and so not to be shown. But such is not the case. The condition requiring prepayment of the first premium is not a contractual term. It is merely the recital of the condition imposed on the insurer's offer of the promise written in the policy; limiting the manner of acceptance. Ordinarily the insured's application is regarded as the offer, and the issuance of the policy as the acceptance of that offer. But here the insurer puts a condition on his acceptance-prepayment of the first premium-which turns it into a counter offer. 41 Thus the tender of the policy is an offer conditioned upon acceptance in a specified manner, that is by prepayment of the first premium in cash. If the offerer wishes to remove this condition, or otherwise modify the mode of acceptance prescribed in the offer, there can be no objection to his doing so. The parol testimony rule, which applies only to promissory provisions of a

${ }^{s 8}$ Wylie v. Jefferson Standard Life Ins. Co. (1913) 95 S. C. 163, 78 S. E. 745.

${ }^{3}$ Home Fire Ins. Co. v. Kuhlman (I899) $58 \mathrm{Neb} .488,78$ N. W. 936; and see Bozeman v. Surety Fund Life Ins. Co. (I92I) I49 Minn. II8, I82 N. W. 99 I.

${ }^{10}$ See cases cited in note 54 , infra.

this process is clearly shown in McKelvie v. Mut. Ben. Life Ins. Co. supra note 19. 


\section{ERRATUM}

Delete first line on page 844 . On page 845 read for first line "written contract, and not to recitals, has no application whatever. The" 
insurer is here said to waive the condition of prepayment contained in the policy. What he really does is to modify the condition imposed upon the policy offer. The question involves the making of the contract, not the operation of a contract already made. The cases rightly hold that the insurer may "waive" this condition, and that such waiver may be shown by parol. ${ }^{2}$

Case (10). Jones' fire policy contains a provision that no action shall be brought thereon unless satisfactory proofs of loss are furnished within sixty days after the fire. Immediately after a fire Jones applies for forms on which to make his proofs of loss, but is told by the insurer that such proofs are not required, all liability under the policy being denied because of breach of the condition against other insurance. Almost without dissent the courts trold that such denial of liability is a "waiver" of the insurer's privilege to require proofs of loss. ${ }^{43}$

Case (II). Jones' fire policy gives to the insurer in case of loss the option to repair or rebuild instead of paying money compensation. The insurer, having by words or acts led the insured to believe that it will pay a loss in money, is said to have waived, or to be estopped from claiming, its option to rebuild, at least when the insured has acted upon the induced belief. Here it is obvious that the policy gives the insurer the privilege of electing between two alternative modes of performance, paying or rebuilding. This privilege once exercised, by electing the one or the other, is thereby extinguished. Although this is a typical example of "election," there is no serious objection to the statement that by electing one alternative the insurer waives his privilege to elect the other..$^{45}$

It is to be noted that while in all of the instances set out above, the waivers are expressly declared by words, they differ from similar

A delivery of the policy without prepayment by an authorized agent with intent to make the contract presently operative "waives" the prepayment. Mut. Reserve Life Ins. Co. v. Heidel (I908, C. C. A. 8th) I6I Fed. 535. See I7 L. R. A. (N. S.) II49, note; Roberts v. Security Co. [I897] I Q. B. III. But not so if there is no such intent. McKelvie v. Mut. Ben. Life Ins. Co. supra note I9; nor if delivery is by an agent without authority to "waive" such condition. Drilling v. New York Life Ins. Co. (I922) 234 N. Y. 234, I37 N. E. 3I4.

"Royal Ins. Co.v. Martin (1904) 192 U. S. 149, 24 Sup. Ct. 247; Feis v. United States Ints. Co. (1924, Neb.) 201 N. W. 558; Radwanski v. Scottish U. \& Nat. Ins. Co. (1924, N. J. Sup. Ct.) r26 Atl. 657; Fed. Life Irus. Co. v. Lewis (rgrg) 76 Okla. I42, $183 \cdot$ Pac. 975.

"See note 52, infra.

45 Mr. Ewart, in his amusing book "Waiver Distributed," fiercely objects to the use of "waiver" in connection with, or, as he thinks, in place of, election. See Ewart, op. cit. supra note 37,25 . "If you had a choice between a horse and a mule, and you chose the horse, you would not say that you 'waived' the mule. For you did not. You had an election between two animals, and, electing to take one, you could do nothing with reference to the other." Ibid. 7. If Mr. Ewart should elect to take the mule, one might accurately enough say he had waived his privilege to take the horse. 
waivers implied from the acts of the parties only in the manner of proof. There may well be great differences of opinion as to whether or not a waiver may be implied from a given state of facts-as for instance, whether retention of an unearned premium after the insurer has learned of a breach of condition justifies the implication of a waiver of such breach ${ }^{46}$ - and the conflict of testimony submitted to a jury may render the result highly uncertain, yet "implied waivers," when once the implication has been made, are not different from express waivers. The fact, however, that implied waivers are established by proof of conduct by the insurer justifying the insured in inferring that he intends to waive, and of conduct by the insured showing that he has in fact drawn such an inference, it is easy to say that when the insured has been misled by the conduct of the insurer, the latter is estopped to deny the truth of such inference. As a consequence, we find the extensive practice of confusing implied waivers and estoppels and regarding the terms as interchangeable. ${ }^{47}$ This is most misleading.

If the eleven typical fact situations set out above are carefully considered, it will be observed that while all the legal relationships created exhibit a common character in that insurer in each expresses an intention to relinquish a privilege accorded him under tine terms of the contract as written, so that all come roughly under the generally accepted definition of a waiver, "an intentional relinquishment of a known right"48 -yet differentiating legal relations cast them into several quite distinct classes, which for convenience we will designate (I) substitute agreements, (II) proper waivers, (III) assumption of excepted risk, (IV) removal of condition upon acceptance, (V) denial of liability, (VI) election. These we will consider separately.

I. Substitite Agreements. In each of the first three cases there is an attempt to show an agreement, possessing all the requisites of a contract, that is, offer, acceptance and consideration, as a substitute for an inconsistent term of the written contract. Evidence is offered for the purpose of changing the terms of the contract as written and delivered. In each case the plaintiff wishes to show that, contrary to the terms of the written contract, the parties really agreed that the insurer's conditional duty to pay should remain unaffected by Jones' entry into military service. As to Case (3), where the modifying agreement, being a promise for an act contemplated and impliedly requested, was subsequent to the delivery of the policy, there is no reason whatever to exclude the proof offered. The law permits the parties to a simple contract in writing to alter its terms by a subsequent

\footnotetext{
${ }^{4}$ See Parsons v. Lane (rgo6) 97 Minn. 98, roti N. W. $485 ; 2$ Williston, op. cit. sec. 757.

"See Richards, op. cit. supra note 27, I59; An er. Dig. tit. Insurance, secs. 388, et seq.; Ruddack v. Detroit Life Ins. Co. (1920) 209 Mich. 638, I77 N. W. 242.

${ }^{43}$ Fed. Land Bank v. Atlas Assur. Co. (I924, N. C.) I25 S. E. 631; Adams v. Hartford Fire Ins. Co. (I922) 193 Iowa, I027, I88 N. W. 823. See Ewart, op. cit. 6 .
} 
parol agreement; $;^{49}$ and in modern times the same rule is applied to a contract under seal if the modifying agreement has been acted on. ${ }^{50}$ - But Cases (I) and (2) are different. There Jones, after or at the time of making his parol agreement, accepts a writing known to be a memorial of the contract and flatly to contradict such agreement. If such an inconsistent parol agreement could be shown under these circumstances, the certainty in contract legal relations so essential to the conduct of business, would be impossible. Therefore the law prohibits it, this prohibition being expressed in terms of the famous and much lauded parol evidence rule. We conclude, then, without any serious difficulty, that these three "waivers" are but modifying contracts, two of which are inoperative to change the legal relations of the parties while the third is fully effective.

II. Proper Waivers. The fourth, fifth, sixth and seventh cases form a second group to which the term waiver is applied in quite a different sense. In none of the cases of this group is there any intention to change a term of the policy but in each the insurer has expressed an intention not to assert an otherwise perfectly good existing defense, and has expressly or impliedly promised not to do so. In the first two cases of the group this promise or "waiver" rests upon a consideration, the payment of a premium not otherwise due, but in the other two no consideration for the promise can be found. Hence we may say that the waiver in the first two of these cases operates as a kind of release of a privilege of defense, but the waiver in the other two cases cannot be so described, as a release not under seal is inoperative in the absence of a consideration. ${ }^{51}$.Therefore this second group of cases may be called proper waivers, since there is no other term that is adequately descriptive. As to the two cases in which no consideration for the waiver is found, the term is fairly distinctive. One writer vehemently asserts that even here there is no proper use for the word waiver; that the insurer has his election in such cases to remain bound or to renounce his obligation, and that when he elects one of these alternatives he is bound by his election, and that is all there is to it. "The case is purely one of election. The default has not only not caused forfeiture of the policy, but has not in the least affected.it. The contract remains as it was until election is made to cancel it. Then it is at an end." ${ }^{\prime 2}$

"An insurance policy, no matter what by-laws are incorporated in it by reference, is but the written expression of a contract, which the parties themselves (not being under legal disability or prohibition) may modify by mutual consent. This is the legal basis of most so-called 'waivers' of conditions in insurance policies." Perrigo v. Comm. Comm. Trav. Mut. Acc. Assoc. (1925, Conn.) I27 Atl. ro, 13, overruling Conghlin v. Knights of Columbus (1906) 79 Conn. 218, 64 Atl. 223. To the same effect is Crowley v. A: O.H.W.\& O. Fund (Igr5) 222 Mass. 228, 1ro N. E. 276.

${ }^{50}$ See 2 Williston, op. cit. sec. 690 .

${ }^{5} 34$ Cyc. ro48. See Fed. Land Bank v. Atlas Assur. Co. supra note 48.

" Ewart, op. cit. 25. 
The author is undoubtedly supported by the overwhelming weight of judicial opinion in saying that the insured's default has not caused forfeiture of the policy, meaning thereby the extinguishment of the legal relations of the parties created by the making of the policy; but he is mistaken in asserting that such default "has not in the least affected" those relations. ${ }^{53}$ The breach of condition has created a most important power-liability relation between the insurer and the .insured. That is, the insurer now has the power and privilege to rescind the contract as of the time of the breach, and the insured is under a liability of losing his rights under the policy by the insurer's exercise of his power. This power to extinguish his own duties under the contract, as well as the insured's rights, the law permits the insurer to relinquish or "waive" by merely indicating by words or acts that he so intends. And the courts are so willing to discover an intention to waive this destructive power that, as will presently appear, they often find sufficient evidence of it in mere silence and inaction on the part of the insurer for an unreasonable time after knowledge of the insured's default. 'But however that may be, it seems clear that the term "waiver" more adequately describes what really takes place than does the word "election," for the insurer's only election is between exercising his power of rescission and waiving it.

III. Assumption of Excepted Risk. In case (8) it is obvious that the insurer never assumed any duty to pay for the loss suffered by reason of the excepted risk. There is no intention to change any term of the policy or to "waive" any breach of condition. No condition is broken. The original contract remains unchanged. It simply does not cover this particular loss. The alleged waiver is merely a new and independent promise to pay money, unenforceable unless sealed or supported by a consideration. ${ }^{54}$ It would be just as reasonable to say that the insurer's unsupported promise to pay for a loss occurring after the expiration of a fire policy is enforceable as to declare that

\footnotetext{
${ }^{83}$ Professor Williston in very different words expresses much the same idea when he says: "The insurer, when taking advantage of a breach of condition, is 'not seeking to rescind the contract sued upon: it is standing upon the contract, and insisting that under its terms there is no liability." " 2 Williston, op. cit. sec. 746, p. I42I, citing Goorberg v. West. Assur. Co. (I907) I50 Calif. 510, 518, 89 Pac. I30. It is submitted that the insurer, by asserting either on the court record or in pais, that he will not pay because of breach of condition, thereby extinguishes not only his own duty to pay, but also any rights he may claim under the policy as an executory contract.

${ }^{54}$ Steil v. Sun Ins. Office (1916) I7I Calif. 795, I55 Pac. 72; Knights, etc. v. Shoaf (1906) I66 Ind. 367, 77 N. E. 738; Ridgeway v. Modern Woodmen (1916) 98 Kan. 240, I57 Pac. II9I; Ruddock v. Detroit Life Ins. Co. supra note 47; Bouman v. Surety Fund Life Ins. Co. supra note 39; Hendrickson v. Grand Lodge (I9I2) I20 Minn. 36, I38 N. W. 946; Draper v. Oswego Co. F. R. Assn. (I907) 190 N. Y. 12,82 N. E. $755 ;$ McCoy v. N.W. Life Ins. Co. (1896) 92 Wis. 577 , 66 N. W. 697 .
} 
the insurer's "waiver" of an exception is binding without consideration. ${ }^{55}$

IV. Removal of Condition upon Acceptance. The offeror may dictate the mode of the acceptance which is to complete the contract, and to that end may impose such conditions as he sees fit on the manner in which his offer is to be accepted. If he wishes he may stipulate that the acceptance of an offer of a promise to insure shall not be complete until the first premium is paid, and if he insists on this condition, no other mode of acceptance will complete the contract. On the - other hand, since the condition is entirely within the insurer's control he may relinquish or "waive" the condition whenever he will. No promise or other term of a contract is involved, for no contract has yet been made. The insurer merely gives up the privilege of insisting upon a given mode of acceptance. For such a waiver it is manifest that no consideration is required. ${ }^{56}$

V. Denial of Liability. When the insurer denies any liability whatever under the contract, as in case (IO), the courts generally say that all conditions still to be performed by the insured are waived. ${ }^{57}$ Here the term "waiver" is used to describe the operation of that long settled rule of law and good sense that when one party to a contract has made the performance of conditions required of the other either impossible or unnecessary, the latter is excused from performance. ${ }^{58}$ Such a waiver has little in common with the others under discussion, unless it be considered that the insurer by his repudiation of the contract intends, as he expressly declares in the case put, to give up his privilege of requiring performance of the condition. ${ }^{59}$ In such cases a consideration for the "waiver" may usually be found in the insured's detrimental inaction induced by the insurer's repudiation, but the excuse for the insured's failure to perform is sufficiently clear under the general rule stated above, and there is no need to invoke the doctrine of waiver or to seek a consideration.

VI. Election. The policy may give to the insurer the privilege of electing between two alternative duties, such as payment or replacement in case of property loss, as stated in case (II). Here it is usually said that by electing to do either one the insurer "waives his right" to

${ }^{s 3}$ See 2 Williston, op. cit. sec. 763; Harper v. Mich. Mut. etc. Ins. Co. (IgIz) I73 Mich. 459, I39 N. W. 27. But where in settlement of a disputed claim, the insurer promises to pay a certain sum, he is liable on such compromise agreement, even though the policy does not in fact cover the loss suffered. The recovery is not on the policy, but on the compromise agreement. Dobbs v. New Amsterdam Casualty Co. (I925, N. J. Ct. Err.) I27 Atl. 209.

${ }^{20}$ See cases cited in note 42 , supra.

${ }^{87}$ See cases cited in note 43 , supra.

is See Williston, op. cit. sec. 677.

${ }^{50}$ Such an expression is, however, meaningless, since the insurer, by his very act of repudiation, extinguishes all his privileges to demand performance on the part of the insured. 
do the other. ${ }^{60}$ It would, perhaps, be more accurate to say that the insurer has reserved to himself the privilege of electing between two alternative duties, and also the power, by expressing his election to fix the right of the insured and his own duty, and likewise to extinguish his own privilege of election. Such a relinquishment of a privilege of election may very properly be called a waiver, evidently very similar to those in Class II above.

\section{Are Watvers Binding Without Consmeration?}

The classification of waivers given above, which could probably be easily extended, shows with sufficient clearness that this elusive term is applied to so many differing legal relationships that the statement of any rule as governing waivers in general is apt to be inaccurate and misleading. This is strikingly illustrated by the statements to be found in the cases with regard to the need of a consideration to support a waiver. The statement most frequently found is that a waiver is not binding unless supported by consideration or an estoppel. ${ }^{.1} \mathrm{By}$ estoppel here is meant the "promissory estoppel" of the text writers," that is, prejudicial action in reliance upon the waiver, which usually is found to be such action as was expressly or impliedly requested, or anticipated by the insurer as a consequence of his promise to waive. Scarcely less frequently it is declared that no consideration is necessary to support a waiver. ${ }^{63}$ Cases may often be found in the same jurisdiction declaring now the one rule and now the other. ${ }^{64}$

\footnotetext{
${ }^{\infty}$ Wynkoop v. Niagara Fire Ins. Co. (1883) 9r N. Y. 478. .Such waiver is irrevocable. Phila. Fire Assoc. v. Rosenthal (I885) 108 Pa. 474, I Atl. 303; Langan v. Aetna Ins. Co. (1900, C. C. N. D. Iowa) 99 Fed. 374. After election by insurer to rebuild, the insured's action is for the breach of a contract to rebuild, and the measure of damages is not limited to the face of the policy. Heilmom $v$. Westchester Fire Ins. Co. (I878) 75 N. Y. 7. The replacement clause in the fire policy is sometimes construed to create in the insurer not an alternative conditional duty, but a power by rebuilding to extinguish the duty to pay money indemnity. Hence it is held that a mere "election" to rebuild does not terminate the insured's right to demand indemnity, which may be enforced if the insurer fails to act on his election by rebuilding. See Gage v. Conn. Fire Ins. Co. (IgIz) 34 Okla. 744, I27 Pac. 407. See 20 L. R. A. (N. S.) 960, note.

as Mobile Life Ins. Co. v. Pruett (1883) 74 Ala. 487; Browson v. N. W. Mut. Life Ins. Co. (I921) 75 Ind. App. 39, 129 N. E. 636; Swedish Amer. Ins. Co. v. Kmitson (1903) 67 Kan. 71, 72 Pac. 526; Fed. Land Bank v. Atlas Assur. Co. supra note 48; Gibson Elec. Co. v. Liverpool, L. \& G. Ins. Co. (I899) I59 N. Y. 418, 54 N. E. 23. See cases cited in Richards, op. cit. I59, I60; I \& 2 Williston, op. cit. secs. 203, 679; Phillips, Insurance (5th ed. 1867) 8, 9; Cooley, op. cit. 2470.

See Williston, op. cit. secs. 139,679 (3).

* Washburn v. Union Cent. Life Ins. Co. (1904) I43 Ala. 485, 38 So. Iorr; Knarston v. Manhattan Life Ins. Co. (1903) I40 Calif. 57, 73 Pac. 740; Phenix Ins. Co. v. Grove (I905) 2I 5 I11. 299, 74 N. E. I4I; Viele v. Germania Ins. Co. (I868) 26 Iowa, 9; Titus v. Glens Falls Ins. Co. (I880) 8I N. Y. 410; Mee v. Bankers' Life Assoc. (I897) 69 Minn. zro, 72 N. W. 74.

${ }^{\text {os }}$ Compare the statement in Draper v. Oswego Co. F. R. Assoc. supra note 54,
} 
The reason for such confusion of statement is not far to seek. When the waiver involved is really a substituted agreement, falling in Class I above, it is of course inoperative without a consideration. ${ }^{65}$ The same thing is true of so-called waivers of exceptions (Class III above).$^{6 e}$ No duty can be created de novo by a naked promise though it be called a waiver. In such cases we might expect the courts to say that a waiver must have the support of a consideration.

On the other hand it is equally clear that the waiver of a condition affecting the acceptance of an offer (Class IV), if made by the offerer who imposed it, needs no consideration, since the only question involved is the intention of the parties to be bound. Neither does waiver by election (Class VI), nor waiver by denial of liability ('Class V), even though in such case a consideration of detriment is usually present. We may naturally expect to find in such cases the statement that waivers require no consideration.

It is in cases involving "proper waivers" (Class II) that serious difficulty is encountered. In cases (4) and (5) a consideration is clearly present, but none exists in cases (6) and (7). Are these latter waivers binding on the insurer? If the language of the policy declaring the contract null and void in case of breach of the condition is taken literally, manifestly all the duties as well as the rights of both parties to the contract were extinguished by such breach, and a duty to pay could not be created de novo by a naked promise. ${ }^{67}$ But these provisions are not so interpreted. They mean merely that the contract becomes voidable at the option of the insurer, ${ }^{68}$ but remains fully

that "It requires no consideration for a waiver, nor any prejudice or injury to the other party," with the opinion in Gibson Elec. Co. v. Liverpool L. \& G. Ins. Co., stipra note 6r.

${ }^{\infty}$ N. Y. Life Ins. Co. v. Dumler (1922, C. C. A. 5th) 282 Fed. 969 ; Patterson v. Amer. Ins. Co. (r912) 164 Mo. App. I57, I48 S. W. 448.

${ }^{*}$ See cases cited supra in note 54 .

${ }^{\circ 7}$ Ruddock v. Detroit Life Ins. Co. supra note 47 ; Old Colony Ins. Co. v. Berryman (1921) I93 Ky. 7, 234 S. W. 748. See 2 Williston, op. cit. sec. 693; Anson, Contracts (Corbin's ed. Igr9) sec. 365 . "It is undoubedly true that where an insurance company is, for any cause, discharged from liability, responsibility for the loss will not re-attach by waiver without proof of the authority in the party whose act of waiver is relied upon, or without a new consideration to sustain it." Imperial Fire Ins. Co. v. Dunham (1888) II7 Pa. 460, 473, I2 At1. 668, 673. See 28 A. L. R. 93, note. And if the contract was really void in its inception because of want of insurable interest, rendering it illegal, no waiver, though expressed in an incontestable clause, can make it valid. See Anstil v. Mfrs'. Life Ins. Co. [1899, H. L.] A. C. 604; Bromley v. Wash. Life Ins. Co. (I906) I22 Ky. 402.92 S. W. I7; Clement v. N. Y. Life Ins. Co. (I898) Ior Tenn. 22, 46 S. W. 56 r.

${ }^{6}$ Glens Falls Ins. Co. v. Michael (I906) I67 Ind. 659, 79 N. E. 905 ; Stiegler v. Eureka Life Ins. Co. (1925, Md.) I27 At1. 397. Statements may occasionally be found to the effect that when a condition expressly (or by interpretation) declares that breach shall render the contract void without further action on the part of the insured, such condition is "self-executing," and the contract cannot be vitalized except to "recreation." See notes in 25. L. R. A. (N. S.) I, 16, 20, 78; Kennedy v. Grand Fraternity (I907) 36 Mont. 325, 92 Pac. 97 I. 
binding on the insured in so far as he may have made promises. ${ }^{69}$ The peculiarity of the insurance contract, however, is that it seldom imposes duties on the insured, but gives him privileges and powers in the form of conditions.

Breach of condition, then, by the insured does not avoid the contract, but gives to the insurer the power to avoid it if he chooses. If he exercises this power and does avoid the contract, he extinguishes all legal relations created by it, and his duty to pay cannot thereafter be recreated without a new contract. ${ }^{70}$ But if he fails to exercise his power to avoid, and, with full knowledge of the breach of condition, remains silent and inactive, what then are the legal relations of the parties? Obviously any duties imposed by the contract upon the insured remain unchanged until the insurer sees fit to exercise his power to avoid. The correlative rights of the insurer likewise must continue. But what has happened to the insurer's duty to pay in case of loss? Has it been extinguished, or does it still exist subject, however, to a power in the insurer to extinguish it by doing a certain act, that is, expressing an intention to disaffirm, or "avoid," the whole contract?

It is argued with much force that since the insurer has a complete defense to any action brought to enforce his promise, he cannot be under any existing duty ${ }^{71}$ and that the pleading of the breach of condition as an affirmative defense ${ }^{72}$ is not to be regarded as an operative fact, the exercise of a power to defeat an existing duty, but merely as a statement necessary to bring the operative facts to the attention of the court. But it is difficult to reconcile this theory of the relationship with the cases involving insurance contracts. In increasing numbers the courts are holding that on breach of condition subsequent the insurer has but a power to disaffirm the entire contract, and that this power must be affirmatively exercised within a reasonable time after notice or be regarded as waived. ${ }^{73}$ The policy may

* Germania Ins. Co. v. Klewer (1889) I29 I11. 599, 22 N. E. 489.

${ }^{70}$ Home Fire Ins. Co. v. Kuhlman supra note 39; Ewart, op. cit. Ior.

${ }^{2}$ See $N$. Y. Life Ins. Co. v. Statham (I876) 93 U. S. 24; Banholzer v. N. Y. Life Ins. Co. (1898) 74 Minn. 387, 77 N. W. 295,78 N. W. 244.

${ }^{73}$ See Richards, op. cit. I55. In some jurisdictions it is held that plaintiff must plead and prove performance of conditions precedent to the inception of the policy. See Benanti v. Del. Ins. Co. (rgI2) 86 Conn. 15, 84 Atl. rog.

${ }^{33}$ Kelley v. Ins. Co. (I914) 262 I11. I58, 104 N. E. I88; Modern Woodmen v. Vincent (I907) 40 Ind. App. 7II, 80 N. E. 427, 82 N. E. 475; Swedish-American Ins. Co. v. Kmutson, supra note 6r; Phoenix Ins. Co. v. Spiers (1888) $87 \mathrm{Ky} .285$, 8 S. W. 453; Phenix Ins. Co. v. Holcombe (1899) 57 Neb. 622, 78 N. W. 300 ; Grubbs v. Ins. Co. (1891) 108 N. C. 472, 13 S. E. 236; Mut. Ins. Co. v. French (I876) 30 Ohio, 240; see also the cases cited in 32 C. J. I3I3, and 8 A. L. R. 398, note. A policy may expressly provide that the insurer's duty to pay shall be merely suspended during a continuing breach of condition. Fireman's Fund Ins. Co. $v$. Lindsey (1924) 32 Ga. App. 683, r24 S. E. 369 (while premium notes remain due and unpaid). So the usual condition of forfeiture is by some courts construed to cause merely a suspension of the insurer's duty to pay during such continuing breach. Port Blakely Mill Co. v. Springfield F. \& M. Ins. Co. (Igro) 59 Wash. 
even be so construed as to require it to be exercised in a very particular way, as by instituting legal proceedings; declaration of intention to rescind and tender of unearned premiums not being sufficient. ${ }^{74}$ It may be extinguished by the expiration of the period fixed by statute, ${ }^{75}$ or by an incontestable clause found in the policy. ${ }^{76}$ Those cases holding that the power to rescind persists until affirmatively waived ${ }^{7 \tau}$ usually involve breach of the condition requiring payment of premiums, which goes to the whole consideration for the insurer's promise to pay, ${ }^{78}$ or they concerned breaches of condition that have come to the knowledge of the insurer only after loss. After loss, when such rights as the insured may have under the contract have become fixed, the

50I, I yo Pac. 36 (sprinkler system out of order). In such cases the insured remains liable on the premium notes in spite of the suspension of the insurer's liability. Fireman's Fund Ins. Co. v. Lindsey, supra. Money paid under a policy cannot be recovered by the insurer upon the ground that after-discovered evidence showed breach of a warranty or condition. Nat. Life Ins. Co. v. Minch (1873) 53 N. Y. 144; Firemen's Fund Ins. Co. v. Vinton (I92x, Sup. Ct. App. T.) 190 N. Y. Supp. 525 .

"Repala v. John Hancock Mut. Life Irw. Co. (1924, Mich.) 201 N. W. 465; Lavelle v. Met. Life Ins. Co. (1922) 209 Mo. App. 330, 238 S. W. 504; Humpston v. State Mut. Life Assur. Co. (1923) I48 Tenn. 439, 256 S. W. 438. But in Minnesota it is held that the incontestable clause does not preclude the insurer from exercising his power of rescission by parol declaration. Indianapolis Life Ins. Co. v. Aaron (1924, Minn.) I97 N. W. 757. See 31 A. L. R. I08-1 18, note.

'By statute in Texas (Vernon's Sayles' Ann. Civ. St. I9r4, art. 4948) the insurer is required to give notice within 90 days after the discovery of a misrepresentation, made in the application for insurance, of his refusal to be bound by the contract. See Guarantee Life Ins. Co. v. Evert (1915, Tex. Civ. App.) I78 S. W. 643 .

${ }^{70}$ Stiegler v. Eurcka Life Ins. Co. supra note 68; Feierman v. Eureka Life Ins. Co. (1924) $279 \mathrm{~Pa}$. 507, 124 At1. 17I; Hardy v. Phoenix Mut. Life Ins. Co. (1920) I80 N. C. 180 , I04 S. E. I66.

" "A waiver cannot be inferred from mere silence. It [the insurer] is not obliged to do or say anything to make the forfeiture effectual. It may wait until claim is made under the policy, and then in denial thereof, or in defense of a suit commenced therefor, allege the forfeiture." Titus v. Glens Falls Ins. Co. supra note 63 , at p. 4I9. Richards, op. cit. sec. I43, and 2 Williston, op. cit. secs. 746, 753, approve this rule. Not so Mr. Ewart, who puts it thus picturesquely: "The effect, then, of the change from 'waiver' to election is that silence-strategy will be as obsolete as flint muskets, and that the law last quoted will be upheld, rather than that which supports the contrary view. If the company wants to cancel the policy, it must so elect. It cannot have a live policy for premium-catching and a dead one for loss-dodging." Ewart, op. cit. 30.

${ }^{78}$ Iowa Life Ins. Co. v. Lewis (r902) 187 U. S. 335, 23 Sup. Ct. 126; Tigg v. Register Life Ins. Co. (Igr I) 152 Iowa, $720, x 33$ N. W. 322 ; Whitlow v. Sovereign Camp (I925, Iowa) 202 N. W. 249; Lightner v. Prudential Ins. Co. (I916) 97 Kan. 97, I54 Pac. 227; Burke v. Prudential Ins. Co. (I915) 221 Mass. 253, ro8 N. E. 1069; Equitable Life Assur. Soc. v. Ellis (rgi2) 105 Tex. 526, I47 S. W. II52; Conway v. Minn. Mut. Life Ins. Co. (I9II) 62 Wash. 49, II2 Pac. II06; Behling v. N.W. Nat. Life Ins. Co. supra note 37. See 8 A. L. R. 395, note, and article by Prof. A. L. Corbin, Supcrvening Impossibility of Performing Conditions Precedent (I922) 22 Cor. L. Rev. 421, 425, 427. 
silence of the insurer as to whether or not he will exercise his power, can scarcely mislead the insured to his prejudice. ${ }^{79}$ Even those courts which refuse to adopt the rule that failure to exercise the power to disaffirm within a reasonable time is to be interpreted as a waiver of such power, seize upon very slight circumstances to show an intention to "waive the forfeiture," that is, to affirm the contract, such as the retention of the unearned portion of a premium, ${ }^{80}$ even in cases where it is doubtful whether the insurer is under any present duty to return such unearned premium. ${ }^{81}$ Furthermore, it may be noted that a pleading is often an important operative fact, ${ }^{82}$ and that it is quite possible to regard a pleading that sets up a breach of condition as an affirmative defense both as an act done in exercise of a power and a fact-communication to the court.

Again the view that on breach of condition by the insured the insurer's duty is extinguished, and not merely rendered defeasible by the exercise of a power, appears inconsistent with the decisions that the insurer in the cases now under consideration may become bound by waivers without consideration. Our law looks with grave disfavor

"Goorberg v. West. Assur. Co. supra note 53; Aetna Ins. Co. v. Mount (19ó7) 90 Miss. 642, 44 So. 162, 45 So. 835;. Benanti v. Del. Ins. Co. supra note 72; Honte Fire Ins. Co. v. Wilson (I9I3) rog Ark. 324, I59 S. W. III3; Steil v. Sun Ins. Office (I916) I7t Calif. 795, I55 Pac. 72; Ruwdell v. Anchor Fire Ins. Co. (1905) I28 Iowa, 575, 105 N. W. I12; New. York Cent. Ins. Co. v. Watson, supra note 37; Betcher v. Cap. Fire Ins. Co. (I899) 78 Minn. 240, 80 N. W. $97 \mathrm{I}$; Gibson Elec. Co. v. Liverpool, L. \& G. Inis. Co. supra note 6r. There are some cases, however, that apply the same rule where the breach of condition was known to the insurer before loss. See Hronish v. Home Ins. Co. (Igr4) 33 S. D. 428 , I 46 N. W. 588 (statute); Moller v. Niagara Fire Ins. Co. (I909) 54 Wash. 439, 103 Pac. 449 (change of interest).

${ }^{\text {so }}$ Allen v. Phoenix Ins Co. (1908) I4 Idaho, 728, 95 Pac. 829; Padrnos v. Cent. Fire Ins. Co. (I909) I42 Iowa, 199, II9 N. W. I33. But a waiver is not so readily implied when knowledge of the breach of condition is first acquired after loss. Thus in Goorberg v. West. Assur. Co. supra note 53, the court said: "Nor can the mere retention of the premium, after the loss has occurred, and where the liability is steadfastly denied, constitute either a waiver of the defense, or an estoppel." To the same effect is Benanti $v$. Del. Ins. Co. supra note 72.

See 2 Williston, op. cit. sec. 757.

Thus the service of the writ in detinue operates as a demand for possession See Vaughn v. Wood (I843) 5 Ala. 304, 307; Tunstall v. McClelland ( $1808, \mathrm{Ky}$.) I Bibb 186, I89; Carraway v. McNeice (1832) I Miss. 538, 540. The prevailing view is that the incontestable clause in life policies renders the setting up of a breach of condition in a proper pleading the only operative fact by which the insurer's power of rescission can be exercised. See cases cited supra note 74 So a statute may provide that a breach of condition can be taken advantage of only by special plea, and not shown under the general issue. Austin v. Prudential Ins. Co. (1925, Me.) 127 Atl. 276 . So payment made on a policy to which insurer has a defense of breach of condition cannot thereafter be recovered unless fraud is shown. See 32 C. J. sec. 639, p. I355, and sitpra note 73. A formal waiver of record made in the course of trial, though without any consideration, extinguishes the insurer's privilege of setting up a breach of condition. Baird v. Kaskaskia L. S. Ins. Co. (I924, Iowa) 200 N. W. 575 . 
upon transactions purporting to extinguish rights or create duties unless they are attended with a prescribed ceremonial, such as livery of seisin, or in later times, the sealing and delivery of a deed, in the case of land, or delivery, in the case of gifts of chattels, or unless they are supported by a consideration received for the right extinguished or the duty assumed. Obviously, the ceremonial or the consideration is required to make sure that the transaction expresses the deliberate intention of the party who is relinquishing the right or assuming the duty. But the law has no great concern for such ephemeral legal relations as mere privileges, or even for a power of defeasance, the so-called "right of forfeiture." Such privileges or power the possessor may give up without either consideration or ceremony. Expressed intention is alone sufficient. Thus a condition in a lease providing that in case of non-payment of the rent the lease shall be void and the term cease is interpreted not literally but as merely giving to the lessor a power of entry. This power the lessor is privileged to exercise or not to exercise as he pleases. Until he exercises it, the rightduty relations of lessor and lessee remain as before the breach of condition. ${ }^{83}$ This privilege and power the lessor may also "waive" without consideration or ceremony. ${ }^{84}$

Quite consistently with these principles the courts hold that the insurer cannot by a mere waiver assume a non-existent duty. An unsupported "waiver of an exception" is not binding ${ }^{85}$ and surely a naked promise made to pay for a loss occurring even a minute after the expiration of the policy would be unenforceable. The influence of this principle is also seen in those cases which declare that a waiver after loss, of a breach of condition occurring before loss, is inoperative without consideration, or "estoppel," whereas such a waiver before loss is binding. ${ }^{86}$ The rationale for such a distinction, which appears to be unsound, seems to be that after the main condition of the contract, the happening of the loss, has been fulfilled, there is no reason for interpreting the silence or inaction of the insurer as indicating an intention to remain bound.

Despite the confusion of statement in the opinions, it is believed that whenever an issue such as that raised in Case (6) as stated above, that is, an unsupported waiver before loss of a breach of condition, has been fairly presented, such waiver has been held binding though

Illinois Surety Co. v. O'Brien (1915, C. C. A. 6th) 223 Fed. 933; Downing v. Cutting Packing Co. (1920) 183 Calif. 91, I90 Pac. 455; Edison Illum. Co. v. Eastern Penn. Power Co. (1916) 253 Pa. 457, 98 Atl. 652.

${ }^{4}$ Rex v. Paulson [I92I, P. C.] I A. C. 27 I. Mere inaction may be such as to show an intention to waive. Cupples v. Level (1909) 54 Wash. 299, ro3 Pac. 430.

${ }^{85}$ See supra note 54 .

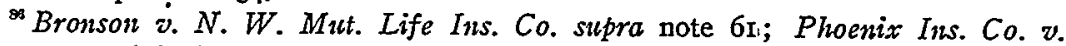
Stevenson (1880) $78 \mathrm{Ky}$. 157 ; Aetua Ins. Co. v. Mount, supra note 79; Pearlstine v. Westchester Fire Ins. Co. (1904) 70 S. C. 75,49 S. E. 4 ; see 25 L. R. A. (N. S.) 3, note. 
without consideration or "estoppel." indicate that the duty of the insurer had not been extinguished by the breach of condition, but that it still persisted, subject, however, to the power of avoidance which the insurer was privileged to exercise. The unsupported waiver, therefore, does not create a duty where none existed before, but does extinguish the insurer's privilege and power to terminate an existing duty.

This discussion makes it clear that a waiver is" conventional in its nature, often taking the form of a true contract. Its very basis is the expressed or implied intention of the possessor of a legal relation to give it up. Hence the well settled rules that the unauthorized acts of an agent cannot create a waiver, ${ }^{88}$ although they may raise an estoppel ; 8 and that acts of the insurer which alone would create a waiver, such as demanding proofs of loss, or participation in appraisals, will not

${ }^{3}$ Ala. Mut. Assur. Co. v. Long Clothing Co. (188g) I23 Ala. 667, 26 So. 655; Caledonian Ins. Co. v. Smith (1913) 65 Fla. 429, 62 So. 595; Home Fire Ins. Co. v. Kuhlman supra note 39; Ohio Farmers' Ins. Co. v. Burget (Igor) 65 Ohio St. II9, 6I N. E. 712; Miller v. Union Indemnity Co. (I924) 209 App. Div. 455, 204 N. Y. Supp. 730; Equitable Life Ins. Co. v. Ellis, supra note 78; Sòthland Life - Ins. Co. v. Hopkins (1920, Tex. Civ. App.) 219 S. W. 254

${ }^{85}$ Ins. Co. v. Wolff (I877) 95 U. S. 326; Conner v. Conn. Fire Ins. Co. (I923 S. D. Fla.) 291 Fed. I05; Porter v. Home Friendly Soc. (1902) II4 Ga. 937, $4 \mathrm{I}$ S. E. 45; Redstrake v. Cumberland Mut. Fire Ins. Co. supra note 24; Baumgartel v. Prov. Wash. Ins. Co. supra note 34 . The occasional decisions holding that limitations upon the agent's authority to waive are invalid are caused by confusing waiver with estoppel. See Peterson v. Modern Woodmen supra note 34, criticised in (I925) 25 Cox. L. REv. I05.

so People's Fire Ins. Co. v. Goyme (1906) 79 Ark. 315, 96 S. W. 365; Parno v. Ins. Co. (IgOI) II4 Iowa, I32, 86 N. W. 210; Security Ins. Co. v. Cameron (Ig̀22) 87 Okla. I7I, 205 Pac. I5I; Wood v. Ins. Co. supra note 36; Sternamart v. Met. Life Ins. Co. (1902) I70 N. Y. 13, 62 N. E. 765; Security Life Ins. Co. v. Calvert (r907, Tex. Civ. App.) 100 S. W. 1033; So. Atl. Ins. Co. v. Hurt (I9I3) II5 Va. 398, $79 \mathrm{~S} \mathrm{E}$. 40I. Frequently this rule assumes the form that limitations upon the agent's authority do not apply to conditions affecting the inception of the policy. Ins. Co. v. Baker (1876) 94 U. S. 6ro; Dulany v. Fid. \& Cas. Co. (1907) 106 Md. I7, 66 Atl. 614. The Federal Courts, making no distinction between waiver and estoppel, persist in holding that the insurer may, by limitation of his agent's authority, exempt himself from liability to estoppel through the agent's unauthorized fraud. N.Y. Life Ins. Co. v. Fletcher supra note I; . Actna Life Ins. Co. v. Moore supra note I. But see Cont. Life Ins. Co.v. Chamberlain supra note $x$. Several of the state courts have accepted this view. See Iverson v. Met. Life Ins. Co. supra note ${ }_{5}$; Salvate v. Firemen's Ins. Co. supra note I5, quoting with approval the following statement from Reed $v$. Equitable F. \& M. Ins. Co. supra note 15, at p. 789, 24 At1. 833, 834; "If this were a new question in this state, we might feel compelled to yield to the weight of authority." And see N.Y. Life Ius. Co. v. Patten supra note I5; Price, How Far does Knozeledge of an Agent Affect the Defense of Frand in an Action on a Life Insurance Policy? (1924) 18 Ir工. L. Rev. 377; reprinted (I925) 59 AM. L. REv. 80. 
have such an effect when, accompanied by notice, either in the policy or elsewhere, that no waiver is intended. ${ }^{90}$

\section{ESTOPPELS}

We now turn to estoppels. Again we will assume fact situations typical of the two groups into which the cases involving estoppels usually fall, and again we will assume that the agent acting for the insurer has full powers.

Case $A$. Jones has erected a building on leased land. He applies for insurance to cover the risk, giving the agent accurate information as to the title. The agent delivers a policy saying, "Here is your policy, fully covering your risk," and collects the premium payable for insurance of the kind applied for. Jones, acting as do a very large majority of ordinary prudent persons under similar circumstances, assumes that the agent has delivered the coverage asked for, and puts the policy in his safe without attempting to read it, knowing full well that he could not understand it if he did so. Therefore he does not learn, until a fire loss occurs, that the policy contains a condition that it shall be void if the building insured is on leased ground.

Case $B$. Jones knows that his policy contains a provision avoiding it in case the building covered remains vacant for more than thirty days unless consent of the insurer thereto is endorsed on the policy. Jones delivers the policy to the agent with a request for such endorsed consent. Thereafter the policy is returned by mail accompanied by a letter from the agent informing Jones that the policy had been properly indorsed according to his request. Again Jones puts the policy in his safe without examination only to discover after a loss that in fact no such endorsement had been made.

Let us consider analytically Case A. We look in vain for the elements of waiver in any of the forms discussed above. There is no agreement before or at the time of the delivery of the written contract altering one of its terms, such as appears in the first two cases of waiver as stated There is no offer, express or implied, by the insurer to make any such agreement, nor is there any acceptance by the confiding insured, who has here no actual knowledge of the

${ }^{\circ}$ See Mason-Henry Press Co. v. Aetna Life Ins. Co. (I9I4) $2 \mathrm{II}$ N. Y. 489. I05 N. E. 826; Tuttle v. Pac. Mut. Life Ins. Co. supra note I5; Reed v. Cont. Ins. Co. (1906 Del.) 6 Penn. 204, 65 Atl. 569. Thus furnishing blanks for proofs of loss does not waive an existing cause of forfeiture, especially if notice is given that no intention to waive exists. But it is otherwise where the insurer requests proofs of loss. See Supreme Tent v. Volkert (I900) 25 Ind. App. 627, 57 N. E. 203, and L. R. A. I9I7 A, r065, note. So the principle does not apply where one is truly put to his election between inconsistent courses. He cannot adopt one course and receive benefits thereunder, and yet retain his privilege of claiming benefits under the other merely by declaring that he does not intend to waive such privilege. See Davenport v. The Queen (1877 P. C.) 3 App. Cas. II5; Craine v. Col. Mut. Fire Ins. Co. (1920 Austr.) 28 C. L. R. 305; 2 Williston, op. cit. secs. 68I, 684, 687. 
existence of the offending condition. There is no evidence whatever of any meeting of the minds of the parties in any attempted modifying agreement, which, of course, could not be shown even if it had been made. We do find, however, all the elements of an estoppel against the insurer who seeks to take advantage of the breach of condition. The insurer has made a false statement of a material fact-that the policy validly covered the risk-knowing that it would be relied on..$^{91}$ The insured relied on the statement, as he had a right to do since he had no actual knowledge of its falsity, ${ }^{92}$ and his failure to read the policy was not such negligence as to impute knowledge to him. ${ }^{93}$ Being so misled he both acted, in paying the premium, and refrained from acting, in that he made no further effort to secure insurance, ${ }^{94}$ both to his prejudice. There seems to be no reason whatever for not holding the insurer estopped to deny the truth of his representation, whether by words, as here, or by acts, as in the more usual case, that the policy was valid at its inception. And of course the parol testimony rule has no application to proof of estoppels, which are shown not to modify any provisions of the contract, but to prevent the insurer from saying that the policy which he had falsely asserted to be valid was really invalid all the time. ${ }^{95}$

\footnotetext{
of "The issuance of the policy by the company is, according to the generally accepted rule, a waiver of a known ground of invalidity, and equivalent to an assertion that the policy is valid at the time of its delivery, although the facts known to the company would, under the express terms of the agreement, render it void or voidable." 32 C. J. 1343 , sec. 618 (4.) See also Bower, op. cit. supra note I8, 37I, et seq.

${ }^{22}$ See Union Mut. Life Ins. Co. v. Wilkinson, supra note 5; Allen v. Phoenix Assur. Co. supra note 80; Lamb v. Conncil Bluffs Ins. Co. (I886) 70 Iowa, 238, 30 N. W. 497 ; McElroy v. British-American Ints. Co. (I889, C. C. A. 9th) 94 Fed 990. Gristock ข. Insurance Co. (I89I) 87 Mich 428, 49 N. W. 634; Bennett v. Insurance Co. (I887) 106 N. Y. 243, 12 N. E. 609; Kister v. Insurance Co. (I889) I28 Pa. 553, I8 Atl. 447.

${ }^{23}$ See note 100, infra.

"Eames v. Home Ins. Co. (1876) 94 U. S. 62; Arnold v. American Ins. Co.
} (I906) I48 Calif. 660, 84 Pac. I82; Thompson v. Traders' Ins. Co. (I902) 169 Mo. 12, 68 S. W. 889; Frels v. Little Ins. Co. (I904) 120 Wis. 590,98 N. W. 522. In England it has been held that in order to establish such an estoppel the insured must allege and affirmatively prove that he "had been prejudically affected by a belief that the defendants were treating the contract as binding." Morrison v. Universal Marine Ins. Co. supra note I8, at p. 206.

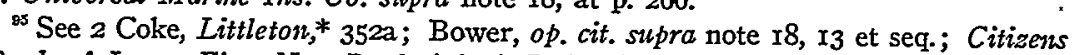
Bank of La. v. First Nat. Bank (I873) L. R. 6 H. L. 352. It is sometimes said that estoppel "is a rule of evidence which precludes a person from denying the truth of some statement previously made by himself." Lindley, L. J. in Low v. Bonverie (I89I) $3 \mathrm{Ch}$. 82, IOI. And see Bower, op. cit. II. But this is a very misleading statement. It does not at all involve the law of evidence. See Ewart, Estoppel (I900) I89. The only reason for the statement made by the courts of Massachusetts, New Jersey and the United States, that parol evidence cannot be admitted to show an estoppel in an action on a written contract of insurance, is that these courts have in mind not estoppels but waivers. They consider that the plaintiff is endeavoring to prove a prior parol agreement inconsist- 
While the doctrine of estoppel by representation has been enforced in courts of law for three centuries, ${ }^{96}$ its equitable origin must not be forgotten. The petitioner for estoppel must have clean hands. His claim must be made in entire good faith. If therefore the insured knew the real facts, he cannot honestly claim that he was misled by the insurer's misrepresentation. If the insured knew or had good reason to suspect, at the time the policy was delivered, that it was void by its terms, he cannot claim that he was misled by the insurer's statement that it was valid. ${ }^{97}$ But to deprive him of his claim of estoppel the insured's knowledge must be such as affects his conscience and negatives his good faith, that is, actual knowledge of the facts involved in the claim of estoppel or of such facts as put him on inquiry. Constructive or imputed knowledge is not sufficient. ${ }^{98}$ The mere fact that

ent with a term of a written contract. Thus in Franklin Fire Ins. Co. v. Martin (I873) 40 N. J. L. 568, 578, it is said: "It is manifest that the theory that such parol evidence, though it may not be competent to change the written contract, may be received for the purpose of raising an estoppel in pais, is a mere evasion of the rule excluding parol testimony when offered to alter a written contract."

${ }^{83}$ In a somewhat embryonic form it was familiar law in Lord Coke's time. 2 Coke, Littleton,* 352a. See Pickard v. Sears (1837, K. B.) 6 A. \& E. 469; White v. Greenish (I86I) II C. B. (N. S.) 209; Stephens v. Baird (I628, N. Y.) 9 Cow. 274; State v. Mut. Life Ins. Co. (1910) I75 Ind. 59, N. E.213; Ewart, op. cit. sitpra note 95,7 .

${ }_{97}$ Obviously if the insured actually knows at the time of the delivery of the policy that it is inoperative because of a breach of condition, he cannot claim an estoppel. Mut. Life Ins. Co. v. Hilton-Greene (19r6) 24ז U. S. 6r3, 36 Sup. Ct. 676; Haapa v. Met. Life Ins. Co. (I907) I50 Mich. 467, iI4 N. W. 380; Mudge v. Sup. Ct. O. I. F. (rgo7) I49 Mich. 467, Ir2 N. W. Ir30; Bratley v. B. O. A. Y. (I924, Minn.) I98 N. W. I28; 3 Cooley, op. cit. 2569; I4 L. R. A. (N. s.) 279, note. Such cases as Huestess v. So. Atl. Life Ins. Co. (Igro) 88 S. C. 31,70 S. E. 403 , Sun Life Ins. Co. v. Phillips (Ig02, Tex. Civ. App.) 70 S. W. 603, and Aetna Life Iis. Co. v. Bockting (I906) 39 Ind. App. 586, 79 N. E. 524, which hold the insurer estopped even though the insured knew of his breach of condition (false statement as to health), and even participated in the fraud of the insurer's agent, cannot well be defended. But even when the insured is not estopped to set up the fraud of the insured at the inception of the policy, his subsequent acceptance of premiums after acquiring knowledge of such fraud, will establish a waiver of the defense. Masonic Life Ins. Co. v. Robirson (IgI2) I49 Ky. 80, I47 S. W. 882 .

${ }^{28}$ Back v. People's Nat. Fire Ins. Co. (1922) 97 Conn. 336, Ir6 At1. 603; Pfiester v. Mo. S. L. Ins. Co. supra note 32; Roe v. Nat. Life Ins. Assoc. (I908) I37 Iowa, 696, II5 N. W. 500; Ameberg v. Cont. Cas. Co. (1922) I78 Wis. 428, I90 N. W. 97. The insured may, without reading the policy delivered to him, assume that it is in accordance with his application. McElroy $v$. British-American Ins. Co. supra note 92; N.W. Nat. Ins. Co. v. Chambers (I922) 24 Ariz. 86, 206 Pac. I08I; Kister v. Ins. Co. supra note 92 . See also cases cited I6 I R. A. (N. s.) I244, note. But not a few states follow the Federal courts in saying that insured must be presumed to know the terms of his contract. $N$. Y. Life Ins. Co. v. Fletcher, supra note I; Layton v. N. Y. Life Ins. Co. supra note I5; Forwood v. Prudential Ins. Co. (IgI2) II7 Md. 254, 83 Atl. I69. 
he has the means of learning the truth for himself does not deprive him of the privilege of relying upon the insurer's representation. ${ }^{99}$ Hence while a general rule of law imputes to the insured knowledge of the terms of the policy which he accepts, such imputed knowledge does not negative his good faith in relying upon a representation made by the insurer as to the operative effect of such policy. Therefore it is no answer to the insured's claim that the insurer is estopped to deny that he is bound by the policy which he delivered as and for a valid contract, to say that he is presumed to know the terms of the policy or that he was not privileged to rely on the insurer's false representation when by reading the policy delivered he might have discovered the truth. ${ }^{100}$

Most cases of estoppel in insurance law involve conditions affecting the inception of the contract, and arise under circumstances that would render "waivers," if really attempted, as in the Case (I) above, inoperative to affect the rights of the parties; but it is quite possible for estoppels to arise after the inception of the contract and to affect the continuance of the insurer's duty validly assumed, as illustrated by the facts assumed in Case (B) stated above. There the defense of the insurer under the vacancy clause would be barred by proof of the transaction whether it be regarded as raising a waiver or an estoppel. Hence in cases where the agent acts within his authority it makes little difference as to results what name may be given to it. But when the officiating agent is without authority to waive, the distinction becomes important, for such limitations do not affect the power of the agent to estop his principal, provided the act done is within the scope of the agent's employment. In Case (B) it is clear that we have no waiver but an estoppel. ${ }^{101}$ To say that the agent by redelivering the unindorsed policy waived performance of the condition is but a misuse of terms. Neither of the parties had any intention of changing a term of the contract, or of making any other kind of waiver. The case shows a statement of fact by the agent which either was or should have been known to him to be false, and prejudicial action by the insured in bona

${ }^{\infty}$ Borries v. Imperial Ottoman Bank (I873) L. R. 9 C. P. 38 (plea setting up estoppel; replication that defendants had "means of knowledge." Demurrer to replication sustained.) See also Greshan Life Assur. Soc. v. Crowther (rgr4) 2 Ch. 2I9 (representee need not search land records to test truth of statement relied on). See Bower, op. cit. stupra note 18 , I73. And see dicta in Duke v. Ashby (1862 Exch.) 7 H. \& N. 600, 602; Morton v. Woods (1869) L. R. 4 Q. B. 293, 303 (where it was stated that tenant claiming estoppel was not charged with notice of contents of deed of lease); Graham v. Thompson (1892) 55 Ark. 296,
i8 S. W. 58 .

${ }^{100}$ See N.W. Nat. Ins. Co. v. Chambers, supra note $98 ;$ Busboom v. Cap. Fire Ins. Co. (I924, Neb.) I97 N. W. 957; Eaton v. Nat. Casualty Co. (I922) I22 Wash. 477, 210 Pac. 779.

${ }^{101}$ Redstrake v. Cumberland Mint. Fire Ins. Co. supra note $24 ;$ No. River Ins. Co. v. Rawls (rgig) I85 Ky. 509, 214 S. W. 925. The English courts find no difficulty in recognizing such estoppels. See Yorkshire Ins. Co. v. Craine (Ig2z P. C.) 2 A C. $54 \mathrm{r}$. 
fide reliance upon that statement. His ability by personal inspection of the policy to discover the falsity of the statement does not under the circumstances deprive him of the privilege to rely upon it.

For the reasons stated, most of the confusion in decision arises in connection with breaches of condition that affect the inception of the policy. Cases (I) and (2) and (A), as stated above, or, more precisely, similar cases in which the statements there expressly made are implied from the conduct of the parties, are typical of the troubled portion of the vast current of "waiver and estoppel" causes now flowing through our courts. Those courts that recognize the distinction between waiver and estoppel sometimes apply to Cases (I) and $(2)$ the same rule of estoppel properly applicable to Case (A), ${ }^{102}$ while some other courts, notably the Federal Courts, apply to Case (A) the same rule that is properly applicable to Cases (I) and (2). ${ }^{103}$ The result in the latter courts is that estoppels are improperly excluded under the rule that properly excludes waivers of the substitute agreement class.

As already shown, clear principle as well as authority precludes the plaintiff in Cases (I) and (2) from asserting a prior or contemporaneous parol modification of the terms of his policy; but unfortunately it is easy to misinterpret the facts of such cases so as to give them the appearance of estoppels. 'Thus it may be said of Case (I) that the insurer is estopped to deny the assurance that the contract would be treated as valid, upon which assurance the insured relied to his prejudice. ${ }^{104}$ But here the elements of estoppel cannot be found. There is no misstatement of fact but a promise not performed. The insured was not deceived but disappointed in his expectation that the insurer would live up to the agent's promise, which, unfortunately for the insured, is unenforceable because of the rule of policy known as the parol evidence rule. The doctrine of estoppel cannot be used to enforce an agreement unenforceable because of that rule, or the statute of frauds or any other rule of policy. ${ }^{105}$ The most that can be claimed for the so-called "promissory estoppel" is to render detrimental conduct in reliance upon a promise a sufficient consideration under circumstances scarcely sufficient to justify the inference that such conduct was bargained for by the promisor. ${ }^{106}$

\footnotetext{
${ }^{102}$ See supra note 32.

${ }^{100}$ See cases cited supra in notes $I, 16$ and 17.

${ }^{10}$ For example see Sovereign Camp $v$. Richardson, supra note 32 (two judges dissenting), with notes in (I922) 3I YALE LAw Journal, 778 and (I922) 6 MrNN. L. Rev. 597. See also Ewart, op. cit. supra note 37, 207.

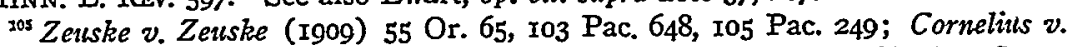
Farmers' Ins. Co. (IgoI) II3 Iowa, $x 83,84$ N. W. I037; Met. Life Ins. Co. v. Hall supra note 3I. "An estoppel cannot arise upon a promise as to future action with respect to a right to be acquired upon an agreement not yet made." Union Mut. Life Ins. Co. v. Mozery supra note 3I. See I6 I. R. A. (N. s.) I255, note; 2I C. J. IIII.

${ }^{100}$ See I Williston, op. cit. sec. I39.
} 
As indicated above, the Federal courts and two of the state courts have fallen into the contrary and even more unfortunate error of assuming that the parol evidence rule, which prevents the enforcement of the substitute agreement "waivers" in Cases (I) and (2), is equally applicable to exclude proof of the estoppel sought to be shown in Case (A). This holding is not due to any unwillingness on the part of the Federal Supreme Court to allow equitable estoppels to be set up in actions at law, for it has permitted such estoppels to be shown even in an action of ejectment to defeat a claim resting upon a clear legal title. $^{107}$ It is rather due to a failure to recognize the existence of an estoppel in such cases as distinguished from a waiver. Throughout the long opinion in the Northern Assurance Company case waiver and estoppel are constantly confused, the ruling idea being that the real purpose of the offered proof, by whatever name called, was to alter the terms of the contract. That this attitude still persists is apparent from the language of the court in Lumber Underwriters $v$. Rife, ${ }^{108}$ where a possible distinction between a waiver and an estoppel is not even suggested, and proof of a clear estoppel is excluded in the belief that it was a waiver.

The same failure to make the distinction between waiver and estoppel, now so firmly fixed by the decisions of the other states, is evident in the opinions of the courts of Massachusetts and New Jersey, although in New Jersey the distinction is clearly discerned and pointed oit in cases like that stated in Case (B) above. ${ }^{109}$ It may be said of the decisions of the courts of these two states, as it cannot be said of those of the Supreme Court of the United States, that they have at least been consistent.

The growing solidarity of the United States as a commercial unit powerfully aids the tendency to make commercial law uniform throughout the nation. It is intolerable that the Federal courts should continue to enforce, with respect to so important a commercial contract as the insurance policy, a rule that has been repudiated by a vast majority of the state courts, and is inconsistent alike with sound reason and fair dealing. Let us hope that the Northern Assurance Company case will soon be added to the list of insurance cases in the Federal Supreme Court reports that have been recently overruled or distinguished away, ${ }^{110}$ and the doctrine of the Wilkinson case re-established.

\footnotetext{
${ }^{207}$ See Drexel v. Bermey (I887) I22 U. S. 24I, 7 Sup. Ct. I200; Kirk v. Hamilton (I880) ro2 U. S. 68.

${ }^{108}$ Suspra note 9.

${ }^{109}$ Redstrake v. Cumberland Mut. Fire Ins. Co. supra note 24.

${ }^{110}$ See Grigsby v. Russell (I9II) 222 U. S. I49, 32 Sup. Ct. 58, which repudiates the doctrine, if not the decision, in Warnock v. Davis (I88I) I04 U. S. 775; and N. W. Mut. Life Ins. Co. v. Johnson (1920) 254 U. S. 96, 4I Sup. Ct. 47, which practically overrules Ritter $v$. Mut. Life Ins. Co. (I898) I69 U. S. 139, I8 Sup. Ct. 300.
} 